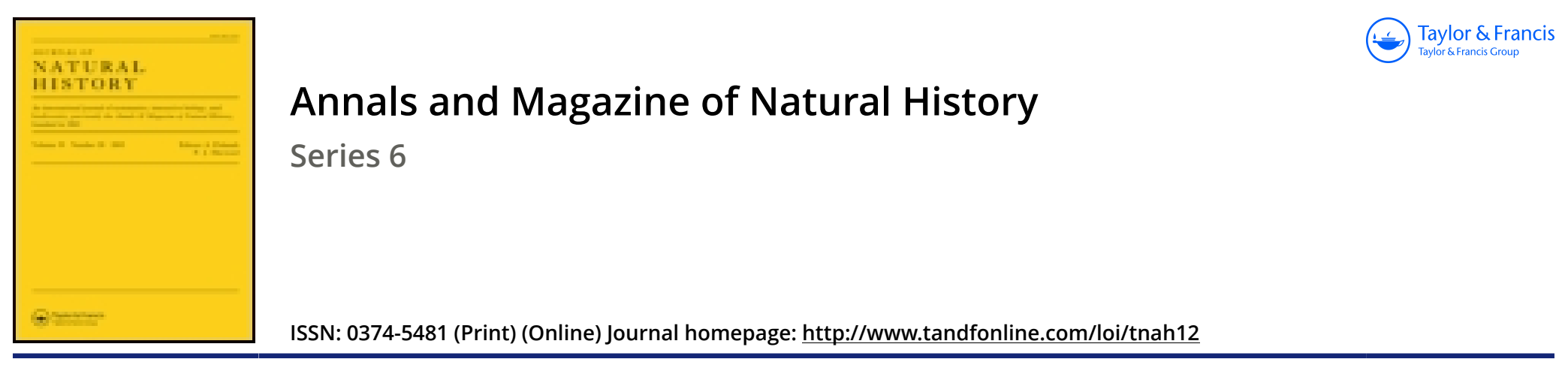

\title{
XXVII.-A revision of the British Jurassic Bryozoa.-Part V. The families Idmoniidæ and Entalophoridæ
}

\author{
J.W. Gregory D.Sc. F.G.S.
}

To cite this article: J.W. Gregory D.Sc. F.G.S. (1896) XXVII._A revision of the British Jurassic Bryozoa.-Part V. The families Idmoniidæ and Entalophoridæ, Annals and Magazine of Natural History, 17:99, 194-201, DOI: $10.1080 / 00222939608680351$

To link to this article: http://dx.doi.org/10.1080/00222939608680351

曲 Published online: 06 Oct 2009.

Submit your article to this journal $₫$

Џll Article views: 3

Q View related articles $\square$

7 Citing articles: 1 View citing articles $\square$ 
Fig. 3. Scorpio fulvipes, nat. size.

Fig. 4. Opisthophthalmus capensis, $\times+$ \%. l.n., longitudinal nerve.

Fig. 5. Uroplectes triangulifer, $\times \frac{4}{5}$.

Fig. 6. Portion of ovary of Scorpio fulvipes.

Fig. 7. Portion of ovary of Euscorpius italious, with unfertilized eggs.

Fig. 8. Portion of the same, with embryos in the ovarian tube.

Fig. 9. Portion of edge of lung-book lamella of Fejovis, sp. (spinous type).

Fig. 10. The same of Euscorpius italicus (arcade type).

Fig. 11. The same of Buthus nigrolineatus (reticulate type).

XXVII.-A Revision of the British Jurassic Bryozoa.- Part V. The Families Idmoniidæ and Entalophoridæ. By J. W. Gregory, D.Sc., F.G.S.

[Continued from p. 155.]

\section{Family Idmoniidæ.}

Diagnosis.-Cyclostomata Tubulata in which the zoceia are simple open tubes and grow into adnate or erect branching: zoaria. The zoarium is branched and the zoccia open only on one side of it. The apertures are arranged in regular transverse series, usually alternately arranged.

\section{Genus Idmonea, Lamouroux, 1821.}

Diagnosis.-Zoarium adnate or erect. Branches ridged or triangular in section. Zoceia in regular, transverse, and usually alternate series. The zoarium is branched and the branches usually radiate from a centre. The branches sometimes anastomose.

Type species : Idmonea triquetra, Lamx. 1821.

\section{Idmonea triquetra, Lamouroux, 1821.}

Idmonea triquetra, Lamouroux, 1821, Expos. méth. p. 80, pl. lxxix. figs. 13-15.

Non 1 dmonea triquetra, Walford, 1889, Bry. Shipton, Part I., Quart. Journ. Geol. Soc. vol. xly. pp. 568, 569, pl, xviii. fig. 13, pl. xix. figs. 3,4 .

Reptotubigera triquetra, d'Orbigny, 1852, Pal. franç., Terr. crét. t. v. p. 751.

Idmonea gracilis, d'Orbigny, 1849, Prod. Pal. t. i. p. 317.

Diagnosis.-Zoarium composed of triangular branches, beside each of which is a thin flat selvage. 'The branches dichotomize repeatedly. 
Zoxcia from 4 to 7 in each series.

Peristomes open along the summit of a low ridge.

Zoceia slender and cylindrical in adult, short, thick, and angular in young stages. Walls punctate.

Distribution.-England: Great Oolite and Bradford Clay. Foreign: Bathonian, France.

\section{Family Entalophoridæ.}

Diagnosis.-Cyclostomata Tubulata in which the zoarium is erect and dendroid; the branches consist of solid bundles of zonecia. The zocecia are monomorphic and open on all sides of the stems.

\section{Genus 1. Entalophora, Lamouroux, 1821.}

Diagnosis.-Entalophoridæ in which the zoarium consists of thin stems, each of which is composed of a small number of zoocia. The peristomes are scattered irregularly. The œcia are cylindrical.

Type species: E. cellarioides, Lamouroux, 1821.

\section{Entalophora cellarioides, Lamouroux, 1821.}

Entalophora cellarioides, Lamouroux, 1821, Expos. méth. p. 81, pl.1xxx. figs. 9-11.

Entalophora laxipora, d’Orbigny, 1849, Prod. Pal. t. i. p. 318.

Entalophora subgracilis, d'Orb., var. corrugata, Walford, 1889, Bry. Shipton, Part I., Quart. Journ. Geol. Soc. vol, xlv. p. 573, pl. xviii. fig. 14.

Diagnosis.-Zoarium cæspitose, composed of thin fragile branches about 1 millim. in diameter.

Zoceia long; the free distal portion is often very long.

Peristomes irregularly quineuncial in arrangement.

Distribution.-England: Inferior Oolite, Great Oolite. Foreign : Bathonian, France.

\section{Entalophora magnipora, Walford, 1889.}

Entalophora magnipora, Walford, 1889, Bry. Shipton, Part I., Quart. Journ. Geol. Soc. vol. xlv. p. 572, pl. xix. figs. 11, 12.

P Entalophora subirregularis, d'Orbigny, 1849, Prod. Pal. t. i. p. 289.

Entalophora raripora, non d'Orb., Walford, 1889, op. cit. p. 572, pl. xix. fig. 10.

Entalophora raripora, Walf., var. anomala, Reuss, Walford, 1889, ibid. p. 573.

Cisternifera clausa, Walford, 1894, ibid. Part II., vol. 1. p. 82, pl. vii. figs. 11,17 .

Cisternifera inconstans, pars, Walford, 1889, ibid. Part II., vol. 1. p. 80, pl. vii. fig. 16. 
Diagnosis.-Zoarium of thin regularly cylindrical branches, composed of about twelve zoocia. Branches 1 to 2 millim. in diameter.

Zoccia long, cylindrical, with only a small portion free. Apertures irregular in distribution, distant. Surface wrinkled,

Distribution.-England: Mid Lias-GreatOolite. Foreign: Bajocian, France?

\section{Entalophora nidulata (Walford), 1894.}

Pergensia nidulata, Walford, 1889, Bry. Shipton, Part II., Quart. Journ. Geol. Soc. vol. 1. p. 73, pl. ii. figs. 1, 2 .

Pergensia major, Walford, 1894, ibid. p. 74, pl. ii. figs. 3, 4.

Pergensia porifera, id. ibid. p. 75 , pl. ii. fig. 6 .

Pergensia galeata, id. ibid. p. 76 , pl. iii. fig. 27.

Pergensia minima, id. ibid. p. 74, pl. ii. fig. 12.

Entalophora richmondiensis, var. pustulopora, Vine, 1884, Polyz. Richmond Boring, Quart. Journ. Geol. Soc. vol. xl. p. 792.

Diagnosis.-Zoarium short, clavate, cylindrical in section.

Zooecia cylindrical, partly immersed, but a free distal portion, the extent of which varies greatly. The apertures are irregularly arranged, but a tendency to a spiniform arrangement occurs in the proximal portion of the zoarium.

Occia large, spherical.

Distribution.-England: Inferior Oolite and Great Oolite.

\section{Genus 2. Spiropora, Lamouroux, 1821.}

Diagnosis._Entalophorida in which the apertures in most parts of the zoarium occur in regular annular or spiral lines. The zoceia are regularly cylindrical.

Type species : Spiropora elegans, Lamouroux, 1821.

\section{Spiropora elegans, Lamouroux, 1821.}

Spiropora elegans, Lamx. 1821, Expos. méth. p. 47, pl. Ixxiii. figs. 19-22.

Cricopora elegans, Blainville, 1830, Dict. Sci. nat. t. Ix. p. 385.

Diagnosis. - Zoarium formed of loose tufts; "branches dichotomize repeatedly, rather stout.

Zoceia long, regularly tubular.

Peristomes slightly elevated, arranged in regular horizontal rows; from 5 to 7 peristomes are seen on each side of a branch; the rows of peristomes are distant, the zoœcia being long.

Distribution. - British : Great Oolite. Foreign: Bathonian, France. 


\section{Spiropora annulosa (Michelin), 1847.}

Cricopora annulosa, Michelin, 1847, Icon. Zooph. p. 339, pl. lvi. fig. 3. Cricopor a verticillata, non Goldf., Michelin, 1846, op. cit. p. 236, pl. lvi. fig. 3 .

Laterotubigera verticillata, d’Orbigny, 1852, Pal. franç., Terr. crét. $t$. v. p. 715.

Cricopora tessonis, Michelin, 1846, Icon. Zooph. p. 236, pl. lvi. fig. 6.

Entalophora tessonis, d'Orbigny, 1849, Prod. Pal. t. i. p. 318.

Spiropora tessonis, Haime, 1854, Bry. jur., Mém. Soc. géol. France, sér. 2, t. v. p. 195.

Cricopora subierticillata, d'Orbigny, 1849, Prod. Pal. t. i. p. 318.

Spiropora straminea (non Phill.), Haime, 1854, op. cit. sór. 2, t. $\mathbf{\text { . }}$ p. 196, pl. ix. fig. 6 .

Entalophore straminea (non Phill.), Brauns, 18i9, Bry. mittl. Jura, Metz, Zeit. deut. geol. Ges. Bd. xxxi. p. 331.

Spiropora ccespitosa (non Lamx.), Haime, 1854, op. cit. p. 195 (excl. syn.), pl. ix. fig. 7.

Spiropora compressa, Haime, 1854, op. cit. p. 197, pl. ix. fig. 5.

Entalophora compressa, Vine, 1888, Polyz. Caen, Journ. Northampton Nat. Hist. Soc. vol, v. p. 10.

Cricopora acutimargo, Waagen, 1868, Zone Amm. Sowerbyi, Geogn. Pal. Beitr. Bd. i. Heft 3, p. 641, pl, xxxiii. fig. 7.

Diagnosis.-Zoarium forming very loose tufts; branches dichotomize irregularly, of medium thickness; section of branches circular, oval, or compressed.

Zocecia regularly cylindrical, rather short.

Peristomes raised and arranged in regular rows; these are horizontal or slightly oblique; from 5 to 7 peristomes can be seen on one side of a branch; the distance between the rows of peristomes is short.

Distribution.-England: Inferior Oolite and Great Oolite. Foreign: Bajocian, France and Germany. Bathonian: France.

\section{Spiropora cospitosa, Lamouroux, 1821.}

Spiropora cespitosa, Lamouroux, 1821, Expos, méth. p. 86, pl. Ixxxii. tigs. 11, 12 .

Non Spiropora caspitosa, Haime, Bry. jur., Mém. Soc. géol. France, sér. 2, t. v. p. 195, pl. ix. fig. 7.

Cricopora caspitosa, Blainville, 1830, Dict. Sci. nat. t. lx. p. 386.

Entalophora caspitosa, d'Orbigny, 1849, Prod. Pal. t. i. p. 318.

Spiropora capillaris, Lamouroux, 1823, op. cit. p. 47.

Cricopora capillaris, Blainville, 1830, op. cit. p. 386.

Intricaria bajocensis, Defrance, 1822, Dict. Sci. nat. t. xxiii. p. 546, pl. xlvi. fig. 1.

Spiropora bajocensis, Haime, 1854, op cit. p. 196.

Laterotubigera bajocensis, d'Orbigny, 1852, Pal. franç., Terr. crét. t. v. p. 715.

Entalophora bajocensis, d'Orbigny, 1852, op. cit. t. v. p. 779.

Pustulopora tenuis, Waagen, Zone Amm. Sowerbyi, Geogn. Pal. Beitr. Bd. i. Heft 3, p. 641 . 
Diagnosis.-Zoarium growing in dense tufts of long slender cylindrical branches; these dichotomize repeatedly and oceasionally anastomose.

Zoceia regularly cylindrical.

Peristomes slightly raised; three or four apertures scen on each side of a branch; peristomial rows very oblique and crowded, and therefore giving the orifices an apparently quincuncial arrangement. At the ends of branches the peristomes are irregular and low (form coespitos $a$, Lamx. \& Mich., non Haime).

Distribution.-England: Great Oolite and Forest Marble. Foreign : Bajocian, France and Germany ; Bathonian, France.

\section{Spiropora richmondiensis (Vine), 1884.}

Entalophora richmontiensis, Vine, 1884, Polyz. Richmond Boring, Quart. Journ. Geol. Soc. vol. xl. p. 791, fig. 3.

Terebellaria? increscens, Vine, 1884, ibid. p. 79.

Diagnosis.-Zoarium of thin bifurcating stems, from 1 to 2 millim. in diameter.

Zocecia numerous, in regular spirals; below the points of bifurcation the rows of peristomes become less oblique and increase to ten in number; elsewhere 7 or 8 zoœcia can be seen in a single row across one face of the stem; zoccia are short and cylindrical.

Peristomes well raised.

Distribution.-Fngland: Great Oolite.

\section{Spiropora tetragona, Lamouroux, 1821.}

Spiropora tetragona, Lamouroux, 1821, Expos. méth. p. 85, pl. 1xxxii. figs. $9,10$.

Cricopora tetragona, Blainville, 1830, Dict. Sci. nat. t. Ix. p. 386.

Entalophora tetragona, dOrbigny, 1849, Prod. Pal. t. i. p. 318.

Bisidmonea tetragona (non Lamx.), Walford, 1889, Bry. Shipton, Part I, Quart. Journ. Geol. Soc. vol. xlv. p. 571, pl, xix. figs. 7-9.

Spiropora tetraquetra, Lamouroux, 1821, op. cit. p. 47.

Cricopora tetraquetra, Bronn, 1835, Leth. Geogn. p. 247.

Bisidmonea antiqua, d’Orbigny, 1852, Pal. franç., Terr. crét. p. 720, pl. 762. figs. 10-12.

Diagnosis.-Zoarium composed of thick tetragonal stems, which dichotomize repeatedly but irregularly; they form a loose tuft.

Zooecia short.

Peristomes slightly raised, arranged in alternate horizontal series (as in Idmonea). On each face of a stem there occui two rows of apertures placed alternately on the left and right 
sides of the face ; the distance between two rows on the same side is of medium length.

Distribution. - British : Inferior Colite. Foreign: Bathonian, France.

Genus 3. Haploceia, gen. nov.

Diagnosis.-Entalophoridæ in which the zoœcia are short and angular in form. The peristomes are never greatly raised; the apertures are small and they are arranged either lineally or quincuncially.

Type species : Haplocecia straminea (Phillips), 1829.

Affinities. - This genus is proposed for some species which differ from Entalophora and Spiropora by having short hexagonal zooecia instead of long regularly tubular ones. As the aperture is not truly terminal and is somewhat contracted, the zocecia show a certain resemblance to those of the Cheilostomata; if the ordinarily accepted definitions of Cheilostomata and Cyclostomata be rigidly applied the members of this genus ought to enter the former order. Some of the species have been included in Melicertites, a genus of which the type species is very uncertain. These forms cannot, however, enter Melicertites, as accepted by Pergens, whose use of this name may be conveniently accepted.

\section{Haploocia straminea (Phillips), 1829.}

Millepora struminea, Phillips, 1829, Geol. Yorks., Part I., Yorks. Coast, p. 143, pl. vii. fig. 8.

Cricopora straminea, Morris, 1843, Cat. Brit. Foss. p. 34.

Intricaria straminea, d'Orbigny, 1849, Prod. Pal. t. i. p. 289.

Non Laterotubigera straminea, d'Orbigny, 1852, Pal. franç., Terr. crót. t. v. p. 715 .

Entalophora straminea, id. ibid. p. 779.

Non Spiropora straminea, Haime, 1854, Bry. jur., Mém. Soc. gǿol. France, sér. 2, t. v. p. 196, pl. ix. fig. 6.

Non Spiropora straminea, T'ine, 1883, Rep. Brit. Assoc. 1882, p. 262.

Pustulopora straminea, Gregory, 1893, Cat. Jur. Bry. York Museum, Rep. Yorks. Phil. Soc. 1893, p. 60, tig. 2.

Pustulopora Quenstedti, Waagen, 1868, Zone Amm. Sowerbyi, Geogn. Pal. Beitr. Bd. i. Heft 3, p. 641, pl. xxxii. fig. 10.

Diagnosis.-Zoarium tufted, loose, and irregular; branches of medium thickness.

Zoccia in regular, horizontal, closely adjoining series, usually hexagonal and bisymmetrical, but variations in grow thpressure render some irregularly polygonal. Aperture transversely elliptical. Peristomes slightly raised. Front wall punctate. 
Distribution. - England: Inferior Oolite - Cornbrash. Foreign: Bajocian, Germany; Bathonian, France.

\section{Haplooecia irregularis, sp. n.}

Diagnosis.-Zoarium composed of small cylindrical stems, which dichotomize irregularly and usually at short intervals.

Zoxcia usually hexagonal, but occasionally heptagonal or pentagonal, often irregular, irregularly quincuncial in arrangement. Apertures large, circular, or, when worn, transversely elongate. Front wall coarsely punctate.

Distribution.-British : Great Oolite, Ancliff, near Bath; Lincolnshire Limestone, Stamford. Foreign: Bathonian, Normandy.

Affinities.-This species is separated from the former one by the irregularly quincuncial arrangement of the zocecia.

\section{Genus 4. Ceriocava.}

Diagnosis.-Entalophoridæ in which the zoarium consists of thick massive stems, each of which is composed of a large number of zoccia. The zoccia are funnel-shaped. The apertures crowded. The peristomes flush. The axis of the zoarium consists of fine zocecia, densely packed. The outer zone consists of zocecia which are usually reflexed and of much greater diameter.

Type species: Ceriocava corymbosa (Lamouroux), 1821.

\section{Ceriocava corymbosa (Lamouroux), 1821.}

Millepora corymbosa, Lamouroux, 1821, Expos. méth. p. 87, pl. lxxxiii. figs. 8, 9.

Non Ceriopora corymbosa, Michelin, 1846, Icon. Zooph. p. 246, pl. Ivii. fig. 9.

Ceriocava corymbosa, d'Orbigny, 1852, Pal. franç., Terr. crét. t. จ. p. 1016.

Heteropora corymbosa, Haime, 1854, Bry. Jur., Mém. Soc. géol. France, sér. 2 , t. v. p. 212.

Ceriopora Neptuni, d'Orbigny, 1849, op. cit. p. 324.

Ceriocara Neptumi, d'Orbigny, 1852, op. cit. p. 1016.

Ceriopora conifera (non Lamx.), Michelin, 1846, op. cit. p. 245, pl. Ivii. fig. 8.

Ceriopora dumetosa, Michelin, 1846, op. cit. p. 245, pl. lvii. fig. 7 .

Cava dumetosa, d'Orbigny, 185\%, op. cit. t. v. p. 1019.

Cava pustulosa, Michelin, 1846, op. cit. p. 245 , p1. lvii. fig. 6 .

Monticulipora pustulosa, d'Orbigny, 1849, Prod. Pal. t. i. p. 323.

Nodicava pustulosa, d'Orbigny, 1852, op. cit. t. v. p. 1014.

Heteropora pustulosa, pars, Brauns, 1879, Bry. mittl. Jura, Metz, Zeit, deut. gool. Ges. Bd. xxxi. p. 336. 
Diagnosis.-Zoarium dendroid, erect, growing in thick, solid branches, which anastomose occasionally. The branches are regularly cylindrical, or compressed (form dumetosa). The surface is level, or raised into pustules (var. pustulata).

Zocecia thin-walled; diaphragms numerous. Aborted zocecia scattered irregularly through the zoarium.

Distribution. - England: Great Oolite and Cornbrash. Foreign: Bathonian, France.

\section{Ceriocava laxata, sp. n.}

\section{Diagnosis.-Zoarium with branches fairly regularly cylin- drical.}

Peristomes irregular in shape, size, and arrangement. Number of zocecia in a branch comparatively limited. The central axis consists of few zoccia, irregularly and loosely arranged.

Distribution.-Inferior Oolite, Leckhampton.

Affinities.-This species is most nearly allied to Ceriocava corymbosa (Lamx.). The differences can be clearly seen in a longitudinal section. The central axis has far fewer zoccia, and these are not so tightly packed. It is not easy to separate the specimens of the two species by the external characters; but the apertures in $C$. corymbosa are more regular than in $C$. laxata.

\section{Synopsis of Species of Entalophoridæ.}

A. Zoceia long and tubular; apertures equal in diameter to zocecia.

I. Branches slender; structure simple.

a. Apertures never in linear series. = Entalophora.

a. Zoarium of long thin cylindrical branches:

(1) free distal end long ............. E. cellarioides.

(2) free distal end short $\ldots \ldots \ldots \ldots \ldots \ldots \ldots, E$. magnipora.

b. Zoarium short, clavate $\ldots \ldots \ldots \ldots \ldots \ldots \ldots$. nidulata.

b. Apertures mostly in linear series. = Spiropora.

a. Apertures in regular horizontal rows:

(1) series of apertures distant ......... S. elegans.

(2) series of apertures close .......... S. annulosa.

b. Apertures in oblique spiral series:

(1) peristomes slightly raised $\ldots \ldots \ldots \ldots$ S. caspitosa.

(2) peristomes well raised .............. S. richmondiensis.

c. Apertures in short alternate series ........ S. tetragona.

II. Branches stout, with a central dense axis. $=$ Ceriocava.

(1) Axis thick $\ldots \ldots \ldots \ldots \ldots \ldots \ldots \ldots \ldots \ldots$

(2) Axis loose and irregular ..............

C. corymbosa.

C. lariata.

B. Zonecia short and hexagonal; apertures contracted. $=$ Haplocecia.

(1) Apertures regularly arranged.

H. straminea.

(2) Apertures irregularly arranged ............. irregalaris.

Ann. dlag. N. Llist. Ser. 6. Vol. xvii. 